Research Article

\title{
An Exploration of Students' Mental Models on Heat and Temperature: A Preliminary Study
}

\author{
Rian Priyadi 1,a,", Markus Diantoro ${ }^{1, \mathrm{~b}}$, Parno ${ }^{1, \mathrm{c}}$, and Helmi ${ }^{2, \mathrm{~d}}$ \\ ${ }^{1}$ Department of Physics, Faculty of Mathematics and Natural Sciences, Universitas Negeri Malang \\ Jl. Semarang 5, Malang 65145, Indonesia \\ ${ }^{2}$ Sekolah Menengah Atas (SMA) Negeri 4 Malang \\ Jl. Tugu 1, Malang 65111, Indonesia \\ e-mail: ${ }^{\text {rianpriyadi94@gmail.com, }},{ }^{\text {b }}$ markus.diantoro.fmipa@um.ac.id, ${ }^{\text {c }}$ parno.fmipa@um.ac.id, and \\ ${ }^{\mathrm{d}}$ helmi.sincera@gmail.com \\ * Corresponding Author
}

\begin{abstract}
The mental models are internal representation possessed by students when learning a concept. This study is intended to explore students' mental models on Heat and Temperature concept. This research was conducted on $11^{\text {th }}$ grade students of Science program $(N=60)$ at one senior public school in Malang. Data were collected through open-ended questions and analyzed using the SSI method, which consisted of three levels of mental models. Based on the results, most of the students are still at the synthetic level. In addition, some differences of the students in visualizing the state of solid atoms during expansion, direction of heat conduction, and direction of heat convection. The future study is expected to explore the mental models of students in other topics of Physics education and make use of appropriate learning models to increase students' mental models.
\end{abstract}

Keywords: exploration, mental models, heat and temperature

\section{Studi Pendahuluan: Eksplorasi Model Mental Siswa pada Materi Suhu dan Kalor}

\begin{abstract}
Abstrak
Model mental merupakan representasi internal yang dimiliki oleh siswa ketika mempelajari suatu konsep. Penelitian ini berfokus mengeksplorasi model mental siswa pada materi suhu dan kalor. Penelitian ini dilakukan pada siswa kelas 11 MIPA (N=60) di salah satu sekolah menengah di Malang. Data dikumpulkan melalui pertanyaan terbuka dan dianalisis menggunakan metode SSI, yang terdiri dati tiga tingkatan model mental. Berdasarkan hasil temuan, dominan siswa masih berada pada tingkatan synthetic. Selain itu, beberapa perbedaan siswa dalam memvisualisasikan keadaan atom-atom zat padat saat pemuaian, arah perpindahan kalor secara konduksi, dan arah perpindahan kalor secara konveksi. Kajian selanjutnya diharapkan mampu menggali model mental siswa pada materi fisika lainnya dan menerapkan model pembelajaran yang sesuai untuk meningkatkan model mental siswa.
\end{abstract}

Kata Kunci: eksplorasi, model mental, suhu dan kalor

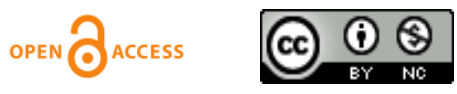


PACS: 01.40.-ed, 01.40.E-, 01.40.Fk, 01.40.Ha, 01.40.ek

(C) 2019 Jurnal Penelitian Fisika dan Aplikasinya (JPFA). This work is licensed under CC BY-NC 4.0

\begin{tabular}{|c|c|}
\hline Article History: Received: January 10, 2019 & Decided to resubmit (Round 1): October 18, 2019 \\
\hline Revised (Round 1): October 30, 2019 & Approved with minor revision: November \\
\hline Accepted: December 3, 2019 & Published: December 31, 2019 \\
\hline
\end{tabular}

How to cite: Priyadi R, et al. An Exploration of Students' Mental Models on Heat and Temperature: A Preliminary Study. Jurnal Penelitian Fisika dan Aplikasinya (JPFA). 2019; 9(2): 114-122. DOI: https://doi.org/10.26740/jpfa.v9n2.p114-122.

\section{INTRODUCTION}

Heat and Temperature are the concept of Physics based on three dimensions, namely macroscopic, microscopic, and symbolic dimensions [1]. The macroscopic dimension examines the learning topics according to its concepts. The microscopic dimension examines the topics based on the interactions that occur in atoms and molecules that make up an object. The symbolic dimension is the formulation concepts of physics through mathematical equations [2,3].

Macroscopic and symbolic dimensions are often applied in learning process. On the other hand, the microscopic dimension has not been applied frequently in the learning process. In fact, understanding in microscopic dimension may help students understand other dimensions [3,4], and Heat and Temperature are one of the concepts of physics that are accommodated in Physics learning through microscopic dimensions [5]. Thus, the microscopic dimension is needed to be applied in order to facilitate the students to understand the concept of Heat and Temperature in Physics education [6].

The mental models are internal representation possessed by students in understanding a concept. Mental models possessed by students illustrate the understanding upon the concepts [3,7], [8]. Mental models will be visible as the students explore their understanding in the three dimensions described [9]. Students' mental model is one of the understandings that should be explored as the analysis of a mental model can be used as an initial diagnosis in learning process [10,11]. Mental models possessed by students vary, as they are influenced by the environment and interactions experienced by the students $[12,13]$. Analysis of the mental models could be used to observe how students think $[14,15]$, learn [16], and predict certain phenomenon $[3,17]$.

Initially, research on mental models has been initially under the cognitive psychology which mainly intends to observe how humans understand, learn, remember [18], [19], and look for systematic explanations related to behavior and cognition [20]. Due to these aspects, mental models can be applied to learn some concepts of Physics [21] in order to provide information on students' behavior in understanding these concepts $[11,22]$.

Information on mental models possessed by the students could be obtained through assessment. Some popular assessment on mental models are employed through interviews, verbal analysis, or even open questions evaluation [22, 23]. Furthermore, the results of the assessment are grouped according to the levels of the mental models using some methods that have been developed, namely ACSMM, MITOCAR, SMD, DEEP, SSI, and PDE [3,24].

Previous research has found the differences on the levels of students' mental models, where dominant students are likely into synthetic and initial levels [25-27]. In 
addition, four different groups of students were found in visualizing the state of solid atoms during expansion [2], five differences in visualizing the direction of heat conduction [28], and seven differences in visualizing the direction of heat convection [10]. Such differences indicate that the students have different understanding on the concepts of Heat and Temperature.

The different levels of metal models possessed by the students indicate that students may have different level of understanding of concepts in Physics education; such differences should become the main concern prior learning activities. Therefore, this study is particularly intended to describe students' mental models that are essential to change their mental models in learning Physics.

\section{METHOD}

This is a qualitative study by nature to explore students' mental models on Heat and Temperature through phenomenology. Subjects involved in this study were $11^{\text {th }}$ grade students $(\mathrm{N}=60)$ majoring on Science Program of one public senior high school in Malang, East Java. A set of test consisting of a description of mental models with the reliability of 0.667 was distributed. The detail questions used in this research are presented in Appendix 1.

As answers from the participants as the data had been obtained, they were analyzed using the SSI method which refers to the rubrics that have been developed [26]. The categorization of students' mental models includes three levels, namely: scientific, synthetic, and initial. Scientific level constitutes students' scientific thinking of the concept they learn so that they are able to relate the phenomena arising during the process with appropriate concepts. Synthetic level describes that students are not consistent in using the concepts; the students analyze phenomena by using irrelevant concepts. Initial level describes that students are not able to connect the phenomena that arise with the actual concept [3].

In addition to grouping into the three levels, the study also describes the microscopic models that appear on the students through visualization of atomic state in the process of expansion and the direction of heat conduction and heat convection.

\section{RESULTS AND DISCUSSION}

This section is divided into two parts, namely the explanation of the distribution of levels of student's mental models and the visualization of students' answers to the microscopic dimensions of Heat and Temperature topic.

\section{Level of Students' Mental Models}

The results of the analysis of the students' mental models categories on Heat and Temperature are presented in Table 1.

Table 1. Students' Mental Models Categories

\begin{tabular}{lcc}
\hline Categories & $\begin{array}{c}\text { Total of } \\
\text { Students }\end{array}$ & $\begin{array}{c}\text { Percentage } \\
(\boldsymbol{\%})\end{array}$ \\
\hline Scientific & 10 & 17 \\
Synthetic & 49 & 82 \\
Initial & 1 & 2 \\
\hline
\end{tabular}

Based on Table 1, it was found that students are mostly at the synthetic level with 49 students (82\%), while students in scientific level are $10 \quad(17 \%)$. This distribution shows the mental model possessed by the students is considered as moderate. Regarding the distribution, it is expected that the Physics educators increase the students' mental models by implementing appropriate learning models. 
Visualization of Students' Mental Models in Microscopic Dimensions

In addition to analyzing students' mental models based on their levels, this study found some differences of the students in terms microscopic dimensions, including the visualization of student's answers, which are elaborated as follows.

Students' mental models on expansion

The students' mental model on expansion was analyzed based on the visualization of the state of heated atoms. Visualization models in expansion are presented in Table 2.

Table 2. The States of Composite Atoms When Experiencing Expansion

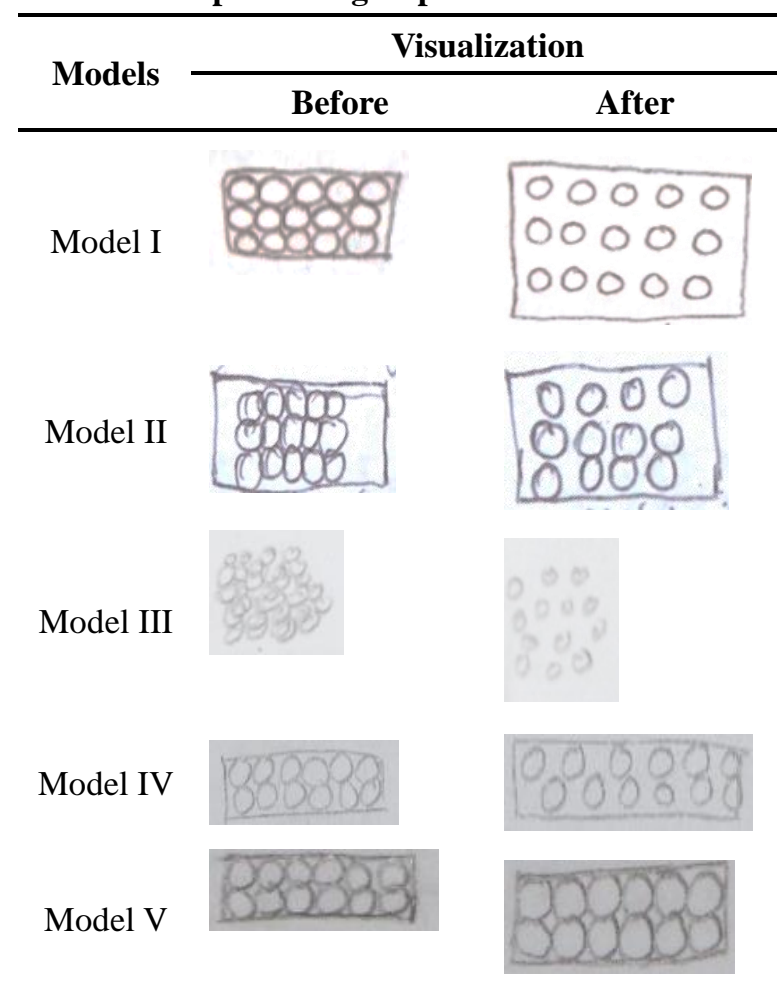

Model I describes that the expansion is caused by the increasing distance among the atoms. Model II describes that the expansion is due to the increasing distance among the atoms, and at the same time, there is reduced quantity of the atoms [2]. Model III describes the expansion process is generally similar to the visualizations of the Model I and Model II. However, it describes such irregular atomic structures before and after the expansion. Model IV describes the state of the atoms before expansion are adjacent and regularly and expand their distance among others as well as change the structure of the atoms [29]. Model $\mathrm{V}$ describes that the expansion occurs due to an increasing volume of the atoms [2].

Students' mental models on heat conduction

The students' mental model in heat conduction was analyzed based on the visualization of direction of heat conduction in heated metal. Visualization models on conduction are presented in Table 3.

Table 3. The Directions of Heat Conduction

\begin{tabular}{|c|c|c|c|}
\hline Models & \multicolumn{3}{|c|}{ Visualization } \\
\hline \multirow[t]{2}{*}{ Model I } & $\$$ & $\circ$ & $\rightarrow$ \\
\hline & A & c & $B$ \\
\hline \multirow[t]{2}{*}{ Model II } & $\because \longrightarrow$ & $-\longrightarrow$ & e] \\
\hline & & $c$ & $B$ \\
\hline \multirow[t]{2}{*}{ Model III } & 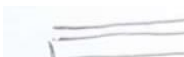 & $\rightarrow$ & $\Rightarrow$ \\
\hline & $A$ & $c$ & $B$ \\
\hline \multirow[t]{3}{*}{ Model IV } & 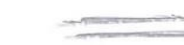 & $\Rightarrow$ & \\
\hline & & $\Leftrightarrow$ & Q \\
\hline & II & $\varepsilon$ & $B$ \\
\hline Model V & $A \frac{n}{3 n}$ & $\mathrm{Cl}_{\mathrm{C}} \mathrm{N}$ & E \\
\hline
\end{tabular}

Model I describes that the heat flows continuously towards the side with lower temperature. Model II shows that heat flows towards the side with lower temperature gradually and occurs continuously [30]. Model III describes that heat flows gradually and moves to the side with lower temperature [31]. Model IV describes that heat flows gradually and at the end downs on the side with lower temperature [28]. Model V describes that heat flows like water flow towards the side with lower and irregular temperature. 
Students' mental models on heat convection

The students' mental models in heat convection were analyzed based on the visualization of direction of heat convection in the heated water. Visualization models on heat convection are presented in Table 4.

Table 4. Directions of Heat Convection

\begin{tabular}{|c|c|c|c|}
\hline Models & Visualizations & Models & $\begin{array}{c}\text { Visualizatio } \\
\text { ns }\end{array}$ \\
\hline Model & & Model & \\
\hline I & $L$ & III & $\downarrow$ \\
\hline Model & & Model & \\
\hline II & & IV & 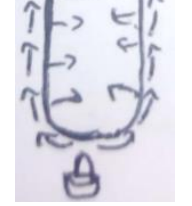 \\
\hline
\end{tabular}

Model I describes that heated water on the lower side increases its temperature, the high-temperature water rises and the cooler one drops. Model II describes that the flow is from higher temperature to lower temperature water without the movement of constituent molecules [25,32]. Model III describes that the heat flows to the tube sides, the water in the middle part is not involved in this process. Hotter water moves up and then backs down after reaching the surface [10]. Model IV describes that the heat flows along the tube, hotter water rises upward while releasing the heat to the surroundings so that all water experiences a rise in temperature.

\section{CONCLUSION}

Based on the results, most of the students are categorized into synthetic level. In addition, differences are also found in students' understanding upon the microscopic dimension. It was found that there are five differences in students in describing the state of solid atoms during expansion. In addition, five models of student's visualization were found in the direction of heat conduction and four models of student's visualization in heat convection.

In terms of the differences of the students' understanding, it indicates that there are some students have incomplete understanding. This may cause wrong interpretation when visualizing the expansion and heat transfer phenomena. The future research is expected to describe possible causes of differences of students' understanding, and appropriate learning models are needed in order to increase students' mental models.

\section{REFERENCES}

[1] Priyadi R, Suryanti K, and Varela L. Profil Model Pemahaman Peserta Didik pada Topik Suhu dan Kalor: Studi Lintas Pendidikan. Jurnal Penelitian Pembelajaran Fisika. 2019; 10(1): 51-56. DOI:

http://dx.doi.org/10.26877/jp2f.v10i1.3461.

[2] Kurnaz MA and Emen AY. Student Mental Models Related to Expansion and Contraction. Acta Didactia Napocensia. 2014; 7(1): 59-67. Available from: http://padi.psiedu.ubbcluj.ro/adn/article 7 1 6.pdf.

[3] Priyadi R, Diantoro M, and Parno. Kajian Literatur: Model Mental dan Metode Evaluasinya. Jurnal Pendidikan Sains (JPS). 2018; 6(2): 70-75. DOI:

https://doi.org/10.26714/jps.6.2.2018.70-75.

[4] Albaiti, Liliasari, and Sumarna O. The Study of Mental Model on N-Hexane-Methanol Binary System (The Validation of Physical Chemistry Practicum Procedure). Jurnal Pendidikan IPA Indonesia. 2016; 5(1): 6-13. Available from: https://journal.unnes.ac.id/nju/index.php/jpii /article/view/5783.

[5] Adadan E and Yavuzkaya MN. Examining the Progression and Consistency of Thermal Concepts: A Cross-age Study. International Journal Science Education. 2018; 40(4): 
Jurnal Penelitian Fisika dan Aplikasinya (JPFA), 2019; 9(2): 114-122

371-396. DOI:

https://doi.org/10.1080/09500693.2018.142

$\underline{3711 .}$.

[6] Kaliampos G and Ravanis K. Thermal Conduction in Metals: Mental Representations in 5-6 Years Old Children's Thinking. Jurnal Ilmiah Pendidikan Fisika Al-Biruni. $\quad 2019 ; \quad$ 8(1): 1-9. $\quad$ DOI: https://doi.org/10.24042/jipfalbiruni.v8i1.37 37.

[7] Haili H, Maknun J, and Siahaan P. Problem Solving Based Learning Model with Multiple Representations to Improve Student's Mental Modelling Ability on Physics. AIP Conference Proceedings. 2017; 1868(1): 070004. DOI:

https://doi.org/10.1063/1.4995180.

[8] Wiji W and Mulyani S. Student's Mental Model, Misconceptions, Troublesome Knowledge, and Threshold Concept on Thermochemistry with DToM-POE. Journal of Physics: Conference Series. 2018; 1013: 012098. DOI:

http://dx.doi.org/10.1088/1742-6596/1013/1 1012098.

[9] Thacker I and Sinatra GM. Visualizing the Greenhouse Effect: Restructuring Mental Models of Climate Change Through a Guided Online Simulation. Education Sciences. 2019; 9(1): 14. DOI: https://doi.org/10.3390/educsci9010014.

[10] Chiou G-L. Reappraising the Relationships Between Physics Students' Mental Models and Predictions: An Example of Heat Convection. Physics Review Special Topics - Physics Education Research. 2013; 9(1): 010119. DOI:

http://dx.doi.org/10.1103/PhysRevSTPER.9 .010119 .

[11] Didiş N, Eryılmaz A, and Erkoç Ş. Investigating Students' Mental Models about the Quantization of Light, Energy, and Angular Momentum. Physics Review Special Topics - Physics Education Research. 2014; 10(2): 020127. DOI:
https://doi.org/10.1103/PhysRevSTPER.10. 020127.

[12] Gray SA, Gray S, Cox LJ, and Henly-Shepard S. Mental Modeler: A Fuzzy-Logic Cognitive Mapping Modeling Tool for Adaptive Environmental Management. Proceedings of 2013 46th Hawaii International Conference on System Sciences. 2013; 1: 965-973. DOI: https://doi.ieeecomputersociety.org/10.1109/ HICSS.2013.399.

[13] Schmidtke JM and Cummings A. The Effects of Virtualness on Teamwork Behavioral Components: The Role of Shared Mental Models. Human Resource Management Review. 2017; 27(4): 660-677. DOI:

https://doi.org/10.1016/j.hrmr.2016.12.011.

[14] Aliberas J, Gutiérrez R, and Izquierdo M. Identifying Changes in a Student's Mental Models and Stimulating Intrinsic Motivation for Learning During a Dialogue Regulated by the Teachback Technique: a Case Study. Research Science Education. 2019; 2019. DOI:

https://doi.org/10.1007/s11165-018-9810-z.

[15] Hartson R and Pyla P. Mental Models and Conceptual Design. The UX Book 2nd Edition - Agile UX Design for a Quality User Experience. Burlington: Morgan Kaufmann; 2018: 327-340.

[16] Docktor JL and Mestre JP. Synthesis of Discipline-based Education Research in Physics. Physical Review Special Topics Physics Education Research. 2014; 10(2): 020119. DOI:

http://dx.doi.org/10.1103/PhysRevSTPER.1 $\underline{0.020119}$.

[17] Utami AD, Sa'dijah C, Subanji S, and Irawati S. Students' Pre-Initial Mental Model: The Case of Indonesian First-Year of College Students. International Journal of Instruction. 2019; 12(1): 1173-1188. DOI: https://doi.org/10.29333/iji.2019.12175a. 
Jurnal Penelitian Fisika dan Aplikasinya (JPFA), 2019; 9(2): 114-122

[18] Rook L. Mental Models: A Robust Definition. The Learning Organization. 2013; 20(1): 38-47. DOI: http://dx.doi.org/10.1108/096964713112885 $\underline{19}$.

[19] Arianti N, Yuliati L, and Sunaryono. Perubahan Model Mental Siswa pada Materi Alat Optik melalui Experiential Learning. Jurnal Pendidikan Teori Penelitian, dan Pengembangan. 2018; 3(5): 575-580. Available from:

http://journal.um.ac.id/index.php/jptpp/artic le/view/11085/5326.

[20] Pitt D. Mental Representation. California: Stanford Encyclopedia of Philosophy Spring 2017 Edition; 2017.

[21] Rahayu S and Purwanto J. Identifikasi Model Mental Siswa SMA Kelas X pada Materi Hukum Newton tentang Gerak. Kaunia Integration and Interconnection Islam and Science. 2013; 9(2): 12-20. Available from:

http://ejournal.uin-suka.ac.id/saintek/kaunia /article/view/1051.

[22] Corpuz ED and Rebello NS. Investigating Students' Mental Models and Knowledge Construction of Microscopic Friction II Implications for Curriculum Design and Development. Physical Review Special Topics - Physics Education Research. 2017; 7: 020103. DOI: http://dx.doi.org/10.1103/PhysRevSTPER.7 .020103 .

[23] Johnson-Laird PN. Mental Models and Cognitive Change. Journal of Cognitive Psychology. 2013; 25(2): 131-138. DOI: http://dx.doi.org/10.1080/20445911.2012.75 9935.

[24] Al-Diban S and Ifenthaler D. Comparison of Two Analysis Approaches for Measuring Externalized Mental Models. Journal of Educational Technology and Society. 2011; 14(2): 16-30. Available from: https://psycnet.apa.org/record/2012-24260$\underline{002}$.
[25] Hendriani $S$ and Suhandi A. An Identification of Students' Mental Model on Heat Convection Associated with the Implemented of Learning Model. Proceedings of 4th International Conference on Research, Implementation and Education of Mathematics and Science (ICRIEMS). Yogyakarta: Faculty of Mathematics and Natural Sciences, Universitas Negeri Yogyakarta. 2017; 77-82. Available from:

http://seminar.uny.ac.id/icriems/sites/semina r.uny.ac.id.icriems/files/prosiding2017/PE1 2_sucihendri.pdf.

[26] Kurnaz MA and Eksi C. An Analysis of High School Students' Mental Models of Solid Friction in Physics. Educational Sciences: Theory and Practice. 2015; 15(3): 787-795. Available from: https://eric.ed.gov/?id=EJ1067435.

[27] Mahardika AI, Fitriah, and Zainuddin. Keterampilan Berargumentasi Ilmiah Pada Pembelajaran Fisika Melalui Model Pembelajaran Inkuiri Terbimbing. Jurnal Vidya Karya. 2015; 27(7): 755-762. Available from:

https://docplayer.info/61909106-Keterampil an-berargumentasi-ilmiah-pada-pembelajara n-fisika-melalui-model-pembelajaran-inkuir i-terbimbing.html.

[28] Chiou G-L and Anderson OR. A Study of Undergraduate Physics Students' Understanding of Heat Conduction Based on Mental Model Theory and an Ontology-Process Analysis. Science Education. 2009; 94(5): 825-854. DOI: https://doi.org/10.1002/sce.20385.

[29] Çökelez A and Yalçin S. The Analysis of the Mental Models of Students in Grade-7 Regarding Atom Concept. Elementary Education Online (EEO). 2012; 11(2): 452-471. Available from: http://ilkogretim-online.org.tr/index.php/io/ article/view/1506. 
Jurnal Penelitian Fisika dan Aplikasinya (JPFA), 2019; 9(2): 114-122

[30] Kakaç S, Yener Y, and Naveira-Cotta CP. Heat Conduction Fifth Edition. Boca Raton: Taylor and Francis Group; 2018. DOI: https://doi.org/10.1201/b22157.

[31] Sari IM, Malik A, Saepuzaman D, Rusdiana D, and Ramalis TR. Pre-service Physics Teachers' Mental Models of Heat Conduction: A Case Study of the Process-analogy of Heat Conduction. Journal of Physics: Conference Series. 2019; 1157(3): 032073. DOI:

http://dx.doi.org/10.1088/1742-6596/1157/3 $\underline{1032073 .}$.
[32] Amalia R, Sari IM, and Sinaga P. Students' Mental Model on Heat Convection Concept and its Relation with Students Conception on Heat and Temperature. Journal of Physics: Conference Series. 2017; 812(1): 012092. DOI:

http://dx.doi.org/10.1088/1742-6596/812/1/ $\underline{012092 .}$. 


\section{APPENDIX 1}

\section{The Questions to the Exploration of Mental Model on Heat and Temperature}

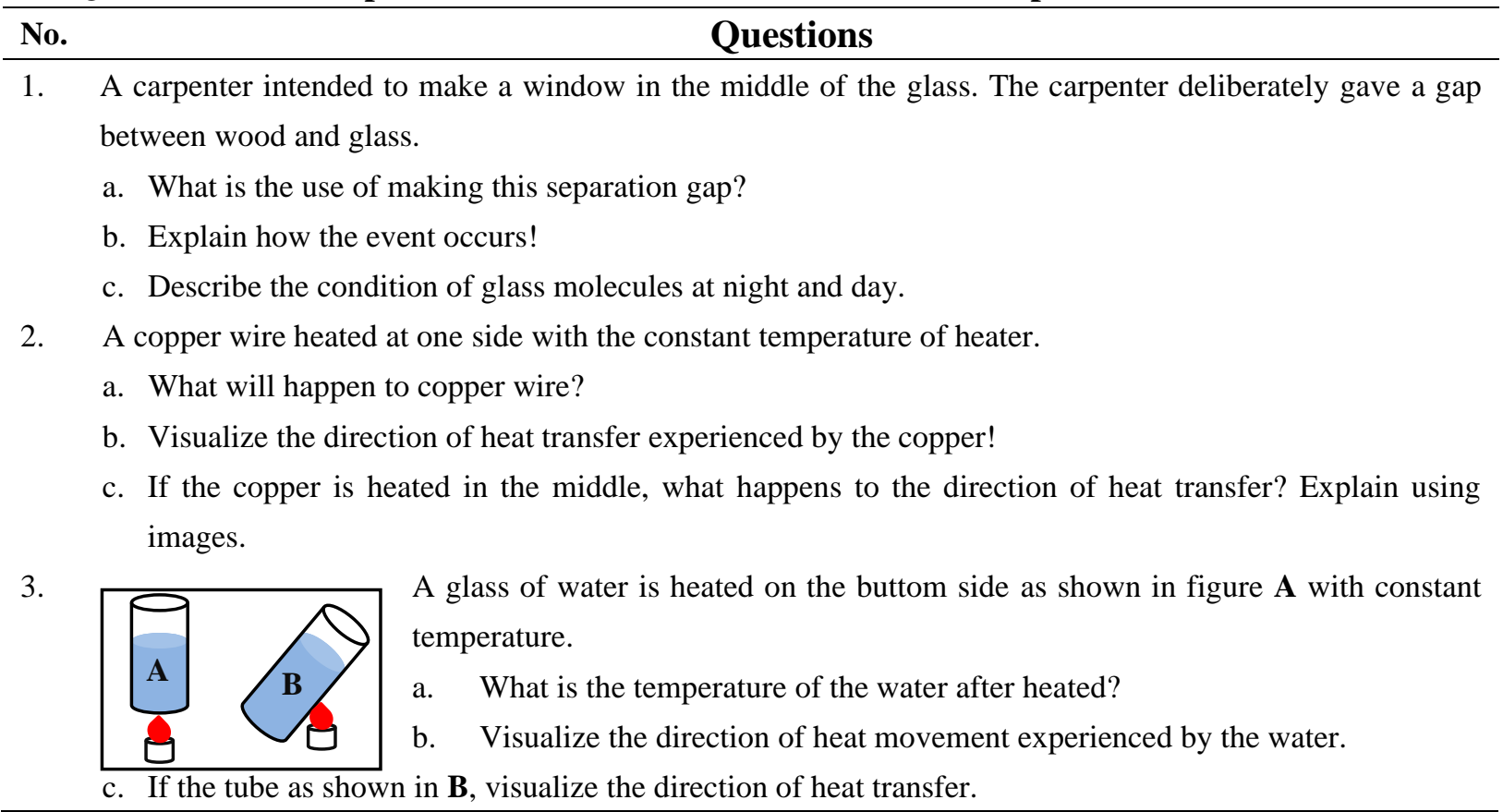

